Uşak Üniversitesi Sosyal Bilimler Dergisi

$2015,8 / 4$

\title{
Refik Halit Karay'ın Sarı Bal Adlı Hikâyesi Üzerine Bir Tahlil Denemesi
}

Ramazan KILIÇARSLAN*

\section{$\ddot{O} z$}

Refik Halit Karay, hayatının büyük bir bölümünü sürgünlerde geçirmiş bir yazardır. Bu sürgünlerin bir meyvesi olan Memleket Hikâyeleri'nde, Türk hikâyesini Anadolu'nun gerçek yüzüyle tanıştırmayı başarmıştır. Sarı Bal adlı hikâyeyi de yazar bu sürgün yıllarında kaleme almıştır. Refik Halit, Sarı Bal adlı hikâyesinde insanların sosyal ilişkilerini, hiyerarşik yapılarını, devlet memurlarının hangi konularda zaaf gösterdiklerini, kasabada yaşayan insanların eğlenme biçimlerini kendine has üslubuyla anlatmıştır. Sarı Bal hikâyesi, şahıs, mekân, dil ve üslup gibi özellikler dikkate alınarak kendi içinde bir bütünlük oluşturacak şekilde ana hatlarıyla ortaya konmuştur. Bu çalışmada yazarın Sarı Bal hikâyesinin kelime sıklığı Türkçe Metin Analiz Programı ile çıkartılmış ve en çok kullanılan ilk yüz kelime üzerinden tahlil edilmiştir. Sıklık çalışması sonucunda çıkarılan ilk yüz kelimenin hikâyenin ana kurgusunu yansıtacak şekilde hikâyede yer aldığı görülmüştür.

Anahtar Kelimeler: Refik Halit Karay, Memleket Hikâyeleri, Sarı Bal, Tahlil, Kelime Sıklı.

\section{An Analysis Essay of Refik Halit Karay's named Yellow Honey Story}

\section{Abstract}

Refik Halit Karay is a writer who has spent a large part of his life in exile. In home town stories which is a fruit of this exile, has managed to introduce the Turkish story with the real face of Anatolia. The author also penned the story Yellow Honey in exile years. Refik Halit in the story called Yellow Honey told some topics with his unique style such as social relations of the people, hierarchical structures, in which issues civil servants showed weakness, fun forms of people living in town. Yellow Honey story was placed to form a coherent outlines taking into account characteristics such as person, place, language and style. In this study, the author's story Yellow Honey's frequency of the words of has been analyzed with the Turkish Text Analysis Program and the story was assayed over the first hundred most

* Yrd. Doç. Dr., Kilis 7 Aralık Üniversitesi, Türkçe Eğitimi Bölümü, ramazankilicarslan@kilis.edu.tr 
commonly used words. In the story of these words whether related to the structure of the text has been examined in the context of factors such as subject, fiction, the character cases. It was seen that a result of study the frequency of first hundred words taking place in the story of extracted as to reflect the main fiction stories.

Keywords: Refik Halit Karay, Hometown Stories, Yellow Honey, Analysis, Word Frequency.

\section{Giriş}

Refik Halit Karay, (1888-1965) ömrünün yaklaşık yirmi iki yılını sürgünde geçirmiş bir yazardır. Karay'ın hayatında iki sürgün dönemi vardır. Bunlardan birincisi 1913'te başlamış 1918'de bitmiş, ikincisi 1922' de başlayıp 1938' de bitmiştir (Karabulut, 2011). Yazarın karakter olarak muhalif bir yanının varlığından söz edilebilir. Belki de bu yanını dizginleyememiş olması sürgünlerinin sebeplerini daya iyi okumamıza yardımcı olacaktır. Gerçi Karay'ın öykücülüğünü belirleyen en önemli nokta da bu sürgün hayattaki izlenimleri, oradaki hayat tarzına tanıklık etmiş olmasıdır. Sürgün yıllarında (1913-1918) bulunduğu Sinop, Çorum, Ankara ve Bilecik gibi Anadolu'nun çeşitli bölgelerinde yakından tanıdığı coğrafyayı ve karşılaştığı insanların öykülerini Memleket Hikâyeleri adlı eserinde derinlemesine anlatmıştır (Şimşek, 2012).

Karay, ilk sürgünde şu hikâyeleri yazmıştır: "Şaka" (1915 Sinop), "Sarı Bal", "Küs Ömer" (1916 Çorum), "Yatır" (1916 Ankara), "Boz Eşek", “Vehbi Efendi'nin Şüphesi” (1918 Bilecik). (Karabulut, 2011).

Refik Halit, sürgünde geçirdiği yaşam kesitlerini anlattığı Memleket Hikâyeleri ile edebiyat dünyasından tam not almıştır. Hikâyelerinde ele aldığı konular arasında o zamana kadar hiç işlenmemiş sosyal problemler, fabrika, işveren-iş̧̧i meseleleri önemli yer tutar. Hikâyelerinde ortaya koyduğu bu konular kendisinden sonra birçok yazarın dikkatini çekmiştir. Bu yazarlar Refik Halit gibi başarılı olamamıştır. "Ne yazık ki açılan bu kapıdan giren sanatçılar, objektiflikte Refik Halit çizgisinde kalamamışlardır. Zira onlar mevcut Anadolu'yu değil, dünya görüşlerini istediği veya o görüşleri işlemeye uygun hayali bir Anadolu meydana getirmişlerdir" (Ekiz, 1999: 38).

Memleket Hikâyeleri, hem Refik Halit için bir dönüm noktası teşkil etmiş hem de Türk edebiyatında, Anadolu içlerinde geçen ilk hikâye örnekleri olmasıyla da bugünkü köy hikâyeciliğimizin gelişmesine imkân tanımıştır. 


\section{Hikâyenin Özeti}

Sarı Bal, Orta Anadolu'da insanları eğlendiren bir çengidir. Kasabanın ileri gelenlerinden biri olan Hilmi Ağa sık sık Sarı Bal'ın bulunduğu eve giderek eğlenmektedir. Sarı Bal kasabada çok meşhurdur; hemen hemen her kesimden onun evine eğlenmeye gelenler vardır. Kasabaya yeni gelen kaymakam bu durumu sonlandırmak için polislere emirler vererek Sarı Bal'ın evinde gördükleri herkesi içeriye almalarını istemektedir.

Kasabaya o gün şiddetli kar yağdığından baskın olmaz düşüncesiyle Hilmi Ağa, yanındakilerle beraber Sarı Bal'ın evine gider. Fakat Sarı Bal onlara kapıyı hemen açmaz. Ve nihayetinde onları içeri alıp eğlence tertip edilir. Rakılar havada uçuşmaktadır. Yerdeki yatakta da Sarı Bal'ın iki oğlundan başka birinin de varlığı görülmektedir. Rakının verdiği sarhoşlukla kimse bunun üzerine gitmez, ta ki polisler evi basana kadar. Evi basan polis memurunun yaptığı aramada yatakta yatanın kim olduğu ortaya çıkar. Yatakta yatan kişi kaymakamdan başkası değildir.

\section{Hikâyenin Ana Unsurlarına Bir Bakış}

Sarı Bal'da yazar Orta Anadolu'da bir kasabada yaşayan insanların cinsel açlıklarını gündeme getirmiştir. Sarı Bal, kasabada tanınan ve hemen her kesimden müşterisi olan meşhur bir çengidir. Karay, herkes tarafından arzulanan bu kadını öyle bir tasvir etmiştir ki bu durum okuyucunun gözünde, insanların onun tuzağına düşmüş olmalarına mazeret gösterecek yapıdadır.

"Çatık kaşları altında şurup gibi tatlı, rayihalı zannolunan, insana öpmek, koklamak, içmek iştihası veren iri, mavi gözleri vardı. Bunlar, bir kaynak gibi, daima parlak ve nemli duruyordu. Zaten gözleriyle kaşı, bir de mini mini, sivri bir sıra mermer beyazlığındaki dişin dizildiği iri ve kırmızı ağzı güzeldi; başka seçme hiçbir yeri yoktu. Yalnız bütün vücudunda, o iri, endamlı dökme kehribar vücudunda öyle bir sokulmak, sürtünmek, bir kedi gibi mırıldana mırıldana yaltaklıklar etmek istidadı göze çarpardı ki işte bu hal, kasaba çapkınlarının uykularını kaçırır, akıllarını alırdı."(Karay, 2009, 72-73).

Sarı Bal'ın böylesine tasvir edilişiyle, hikâyede yer alan memur/bürokrat, eşraf başta olmak üzere hemen her kesimden hovardalık yapmak isteyenlerin bu kadına karşı gösterdikleri zaaf gözler önüne serilmiştir. Yukarıda ifade edilen "sokulmak", "sürtünmek" ve "mirlldana 
mırıldana yaltaklıklar etmek" eylemleri ve söz öbeğinin verdiği etki, uykular kaçırmak ve akılları almak eylemlerine sebebiyet vermektedir. Böylece Sarı Bal karşı konulmaz bir cinsel objeye dönüştürülmüştür.

Hikâyede Sarı Bal'ın çengilik yaptığı mekân, Refik Halit'in realist bakış açısıyla yansıtılmıştır. Yazar, mekâna yüklediği ironi üzerinden insanların zaaflarını yüzlerine çarpmıştır. Sarı Bal'ın evi, bir cazibe merkezi gibidir. Onun yaşadığı evin tasviri verilirken göze, burna, deriye ait ihsaslardan faydalanılmıştır (Aktaş, 2004, s. 131).

"Burası, penceresi, nefesliği olmayan çukur, basık, loş bir yerdi; ahıra benziyor ve ahır kadar kokuyordu. Dışarıdan yeni girince keskin ve ekşi bir yaşlık, gözleri sulandıran bir sirkeleşmiş hava insanı tıkıyor, değişmeye değişmeye çürümüş zannolunan sıcak, fena bir yağ gibi çehreye yapışıyordu. Duvarda elekler, sepetler asılıydi; tavandan torbalar, soğan dizileri, ayva hevenkleri sarkiyordu" (Karay, 2009: 70).

Sarı Bal'da kasaba yaşamının yönetim hiyerarşisi için de bazı ipuçlarına rastlamaktayız. Kasaba sosyal hayatına yön veren iki katmandan bahsedilebilir ve bu eşraf-bürokrat çekişmesi, memur-bürokratların yozlaşması olarak karşımıza çıkar (Gözütok, 2007). Aktaş'a göre ise (2004: 69) bu hikâyede bahsi geçen erkekleri sosyal mevkilerine göre iki grupta toplanmıştır:

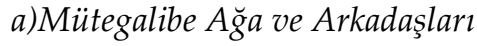

b)Memur ve Amirler

Külahçızade Hilmi Ağa, kasabada yukarıda ifade edilen "mütegalibe ağa ve arkadaşları" kısmında yer almaktadır. Kaymakam ve kolluk kuvvetleri ve memur takımına karşı Hilmi Ağa'nın bir ağırlığı vardır. Hilmi Ağa'nın eserde de anladığımız bazı misyonlarının, yüksek mevkilerde dayı takımının olduğunu ve bunun onu el üstünde tutulur bir noktaya getirdiği söylenebilir.

"Kasabanın bu adlı sanlı mirasyedisi, bu yarı çılgın hovardası bir eve girmek ister de hiç önüne geçilir miydi?"(Karay, 2009: 70).

Sarı Bal'ın evine baskın yapan polislerin kapıları vurması üzerine bile hiçbir tevahhuşa düşmemiş soğukkanlılığını yitirmemiştir. "Külâhçızade "açın be, gelsin!" diye haykırdı. Onun pervası yoktu. Memleketin o kadar eski, itibarlı hükümetinden daima yumuşak, geçiştirici muamele görür, fakat buna mukabil hicaz şimendiferi ianesinde, eşkıya takibinde tesirli yardımcı olurdu; dayılarından biri de Yıldız'da bekçibaşı idi."(Karay, 2009: 76).

Refik Halit, bu hikâyesinde Sarı Bal'a karşı koyamayan bazı karakterlere de yer vermiştir. Bazı memurların hatta Kaymakam'ın bile Sarı 
Bal'a karşı koyamadığı gerçeğini büyük bir ironi ile gösterilmiştir. Karay, bundan daha büyük bir çatışmayı da yine Sarı Bal'a zaafı olan imam üzerinden vermeye çalışmıştır.

"Acaba bu murdar yer odasina kimler misafir olmazdı? Yerliden, yolcudan, memurdan her çeşit müşterisi vardı. Bir mal müdürü, Sarı Bal'ın uğruna kasasında açık vererek perişan olmamış mıydı? Şimdi Akkâ'da kalebentti ahbaplarına gönderdiği mektuplarda hâlâ onu soruyor, onun hatırasını kaydediyordu. Camiikebir'in o azametli sofu imamin bile bir gece burada basıvermişlerdi." (Karay, 2009: 74).

Refik Halit, Anadolu'da yaşayan insanları farklı açılardan ele almış, onların ahlaki duruşlarını, yozlaşmış hallerini, kadına gösterdikleri zaafı görevli memurların gülünç hallerini gözler önüne sermiştir. Bu açıdan da kendisinden sonra gelenleri etkilemeyi başarmıştır. "Öykülerin yazıldığı tarihler/dönemler düşünüldüğünde onun öncülüğü daha iyi anlaşılır. "Yatık Emine", "Sarı Bal" öykülerinde gündeme getirdiği "uygunsuz kadın" tiplemeleri ve yozlaşmış bürokrasi, başta Sabahattin Ali olmak üzere kendinden sonraki pek çok sanatçııı etkilemiştir." (Tosun, 2010). Nitekim bu konuda Aktaş da (2004: 114), şunları söyler:

"Refik Halit, memurların komik yönlerini ortaya koyduğu gibi; hocaların da yüklendikleri mesleğin ulviyeti ile bağdaşmayan kararlar verdiklerini, tavırlar takındıklarını hikâye eder."

Bu bağlamda Karay, Sarı Bal'da da imamı yukarıdakileri destekler nitelikte tasvir etmiştir. Fakat burada imamın Sarı Bal'a tutulmasını nefsi bir istek, ya da bir insanın nefis mücadelesini kaybetme olarak yorumlamak hikâyede işlenen Sarı Bal'ın cazibesi bakımından daha doğru olacaktır. Bir başka nokta ise imamın "azametli" ve "sofu" olarak nitelendirilmesi ve yüklemini tezlik fiiliyle verilmiş olması önemlidir. Çünkü Hilmi Ağa'nın ya da arkadaşlarının belki kaymakamın bile Sarı Bal'la olması bir noktada açıklanabilir. Din önderlerinin böyle bir cürümde basılıvermesi ve yakalanıvermesi iki uç noktanın kesişmesinin çarpıcı bir örneği gözler önüne serdiğinden açılanması zor bir durumu teşkil eder. Belki yazar bu zorluğu "azametli" ve "sofu" sıfatlarıyla da daha zorlaştırmak istemiştir.

Sarı Bal, bala benzetiliş biçimiyle de dikkatlerimizi çekmektedir. Bal gibi şifa kaynağı, ağızlarda hoş bir tat bırakan bu gıdanın Sarı Bal olup sinelere akması, karakteri çok daha çekici hale getirmiştir. O çengi "bal gibi tatlıdır" mesajı verilmek istendiği apaçıktır. Lakin burada dikkat edilmesi gereken nokta her gida gibi balın da fazla tüketimi insanda değişik sıkıntılara yol açmaktadır. Nitekim Tahmisoğlu Feyzi adında zengin biri Sarı Bal için tüm parasını harcamıştır. 
"Zavallı delikanlı parayı yiyip bitirince reji kolcusu yazılmış ve Çerkezlerle olan bir kavgada belkemiğinden vurularak tam yedi sene kötürüm yaşamıştı, sonra verem imdadına yetişip kurtulmuştu"(Karay, 2009: 73).

Anlatıc1, Sarı Bal'ın yol açtığı trajediyi bir fotoğraf gibi çekip göstermiştir. Feyzi'nin yaşadığı sıkıntıların son bulmasını "verem imdadına yetişip kurtulmuştu" diyerek özetlemesi çarpıcıdır. Sadece Feyzi değil; bunun yanında mal müdürü de kasasında açık verip mahvolmuştur. Anlatıcı, Sarı Bal'ın verdiği tahribatı şu şekilde ifade etmiştir:

"Sarı Bal, kasabanın felâketiydi. Sık sık taşıp köprüleri götüren deli çay, damları çökerten karayel, bağları soyan dolu kadar zararlıydı. Onun da götürdüğü çiftlikler; çökerttiği damlar, soyduğu bağlar vardı. Hemen her mirastan hakkı, her kazançtan hissesi olurdu" (Karay, 2009: 74).

Refik Halit, eserlerinde İstanbul Türkçesini kullanmıştır. Fecr-i Ati topluluğunda yer almasına rağmen Yeni Lisancıların istediği tarzda pürüzsüz bir dil ile eserlerini neşretmiştir. Ziya Gökalp onun için: “Türkçeyi en iyi yazan muharrir Refik Halit'tir" demiştir (Yardım, 1997: 43). Dili iyi kullanmakla kalmamış, tasvirlerini son derece sağlam bir şekilde oluşturmuştur. Anlatıcı Sarı Bal'da dili çok sade bir şekilde kullanmış yerel unsurlara fazla yer vermemiş̧tir. Zaten onun hikâyelerinde ağız ve şiveler basit ve sınırlı bir alandadır. İstanbul Türkçesi tüm güzelliğiyle eserlerinde kendini gösterir. Hikâye, Orta Anadolu'nun şirin ili Çorum'da geçmektedir. Bu yörelerin ağız özelliklerini Hilmi Ağa'nın konuşmasında görmekteyiz. "Kız, açıver, bizik, ne duruyonuz!" bizik şeklinde bir konuşma ve ne duruyonuz? sorusunda nazal n'ye yapılan vurgu görülmektedir. Başka yerde de "abanın behe" şeklindeki konuşmalar yerellikle ilgili bu ifadelerle sınırlandırılmıştır.

Karay'ın öykülerinde anlatıma hareket kazandırmak, tasvirleri canlı tutmak için ikilemeler sıklıkla kullanılmıştır. Acele acele, değişmiye değişmiye, mânasız mânasız, alev alev, sarara sarara, mini mini, mırldana mirıldana, fikır fikır, sık sık, ă̆ır ağır, birer birer, ĭgri büğgrü, dik dik, söyleye söyleye.

Yazar, bugün belki çok kullanılmayan bazı kelimelerle karşımıza çıkmaktadır. Özellikle "muttasıl" ve "mütemadiyen" kelimeleri üzerinde durmak gerekmektedir. Bunlar metnin çözümlenmesinde iki önemli anahtar kelime olarak karşımıza çıkmaktadır. Sarı Bal'ın kapısı için anlatıcı şöyle demektedir: "Tokmak muttasıl dövülüyordu." Sarı Bal'ın kapısının "muttasıl" dövülmesinin onun ne kadar istenilen birisi olduğu gerçeğini de akıllara getirmektedir. Bunun yanında Sarı Bal'ın evinde eğlencenin mütemadiyen devam ettiğini de görmekteyiz. "Yalnız boğuk, kaba sesli ziller bu tembel saz ve tembel oyun içinde bir elektrik cereyanına tutulmuş gibi mütemadiyen çırpınır, 
çınlardt."(Karay, 2009: 73). Anlatıcının bu eğlence merkezini kapısının muttasıl dövüldügü ve zillerin mütemadiyen çalındığı bir yer olarak tasviri ne kadar da başarılıdır.

Anlatıcı hikâyesini traji-komik bir sonla bitirmiştir. Hilmi Ağa'nın gözü önünde yakalanan kaymakam görevinden istifa etmek zorunda kalmıştır. Toplumsal koşullara ve kendisine yenilen bir kaymakam portresi ortaya koymuştur. Mizahi ve ironiyi bir anlatım imkânı olarak gören Karay, ikisine de bu hikâyesinde yer vermiştir.

\section{Araștırmanın Amacı ve Önemi}

Bu çalışmada, Refik Halit Karay'ın Memleket Hikâyeleri adlı eserinde yer alan Sarı Bal adlı öyküsünün kelime sıklığı çıkartılmıştır. En fazla kullanılan ilk yüz kelime tespit edilerek metnin iç yapısının kelime sıklığı bağlamında tutarlılık gösterip göstermediği amaçlanmıştır. Hikâyede tespit edilen ilk yüz kelime ve bu kelimelerin oluşturduğu anlam düzeyleri metnin iç yapısının tümel olarak değerlendirmesine olanak vermiştir.

\section{Araştırmanın Yöntemi}

Bu çalışmada nitel araştırma yöntemi kullanılmıştır. Çalışmada elde edilen bulgular nitel veri analizi yapılarak yorumlanmaya çalışılmıştır. Özellikle verilerin sayısal analizi üzerinde durulmuştur. Genellikle nicel verilerin analizinde sayısal analiz yapılırken nitel verilerin analizinde yapılmaz; fakat bazı durumlarda sayısal analiz sayısallaştırmanın güvenirliğini arttırmak, yanlılığ 1 azaltmak ve verilerin analizi sonucunda ortaya çıkan tema ve kategoriler arasında karşılaştırma yapmamıza olanak verir (Yıldırım ve Şimşek, 2013).

\section{Evren ve Örneklem}

Çalışmanın evrenini, Refik Halit Karay'ın Memleket Hikâyeleri adlı eseri oluşturmaktadır. Örnekleminde ise bu hikâyeler içerisinde yer alan "Sarı Bal" seçilmiş ve bu eserin tahlili yapılmaya çalışılmıştır.

\section{Verilerin Analizi}

Verilerin analizinde Prof. Dr. M. Kara ve A. Kurt'un birlikte geliştirdikleri Türkçe Metin Analiz Programı kullanılmıştır. http://ihaleka.com/metinanaliz/ adresinden ulaşılan programa, hikâye metni girilerek kök ve gövde sıklığı çıkartılmıştır. 


\section{Bulgular}

Sarı Bal hikâyesinin, Türkçe Metin Analiz Programı kullanılarak sıklık çalışması yapılmıştır. Metinde en çok tekrarlayan ilk yüz kelime tespit edilmiş ve bunlar tabloda gösterilmiştir. Tabloda gösterilen bu kelimeler "gövde", "sıklık", "yüzde" ve "sıklık dağılımı" şeklinde ele alınmıştır.

Tablo 1. Sarı Bal Hikâyesinin Gövde Sıklığ1- İlk Yüz Kelime

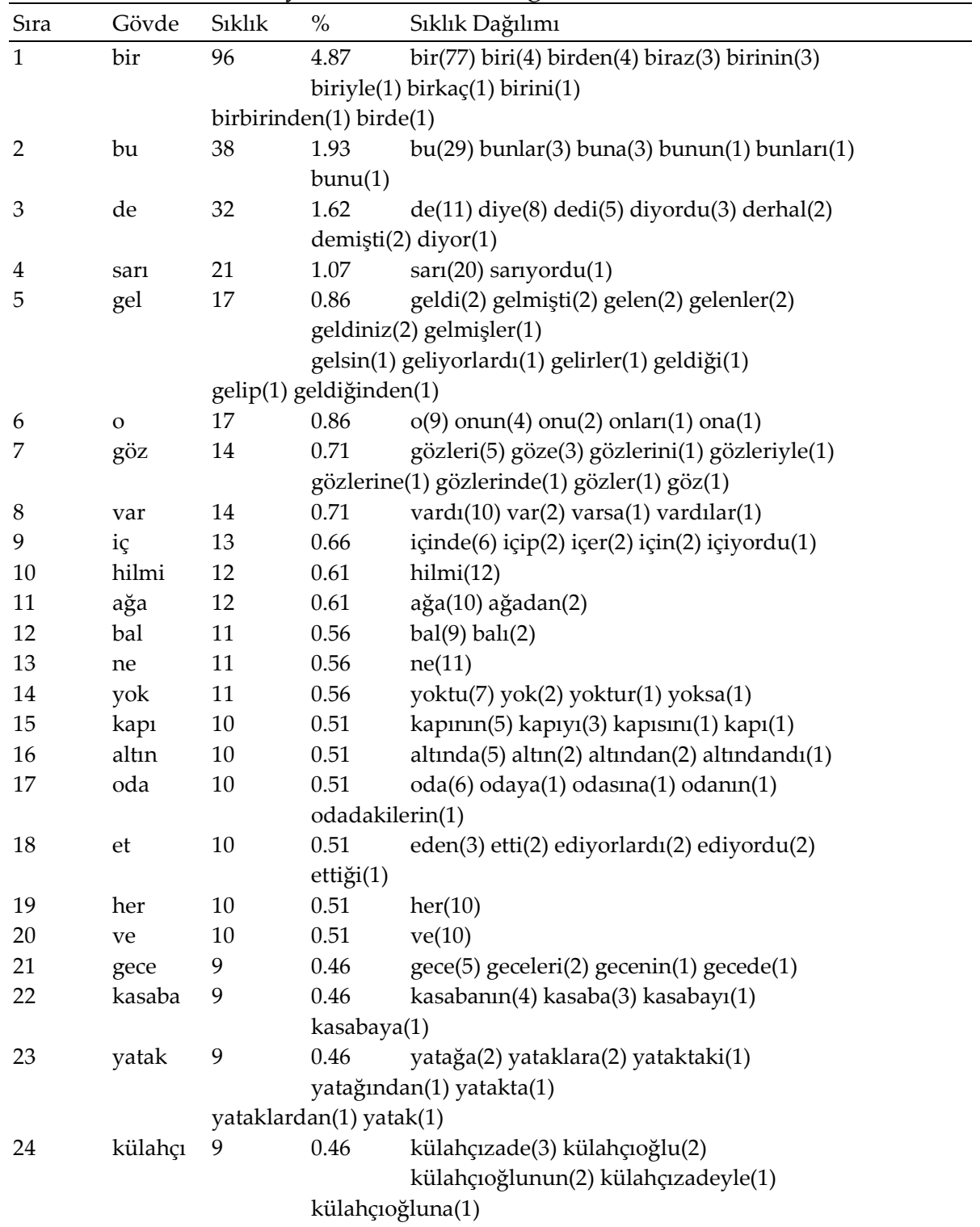




\begin{tabular}{|c|c|c|c|c|}
\hline 25 & şimdi & 9 & 0.46 & şimdi(8) şimdiden(1) \\
\hline 26 & balın & 8 & 0.41 & balın(8) \\
\hline 27 & gibi & 8 & 0.41 & gibi(8) \\
\hline 28 & geç & 8 & geçen $(1)$ geçtikten $(1)$ & $\begin{array}{l}\text { geç(3) geçtiğini(1) geçtiler(1) geçerek(1) } \\
\text { geçtikten(1) }\end{array}$ \\
\hline 29 & birer & 8 & 0.41 & birer(8) \\
\hline 30 & zil & 8 & 0.41 & zillerini(3) zil(2) zillerin(1) zilleri(1) ziller(1) \\
\hline 31 & $\mathrm{i}$ & 8 & 0.41 & $\operatorname{idi}(8)$ \\
\hline 32 & yar1 & 8 & 0.41 & $\operatorname{yar1}(7)$ yarısı(1) \\
\hline 33 & sik & 8 & 0.41 & $\operatorname{sik}(8)$ \\
\hline 34 & kadar & 8 & 0.41 & kadar(8) \\
\hline 35 & iki & 8 & 0.41 & iki(7) ikide(1) \\
\hline 36 & komiser & 7 & 0.36 & komiser(6) komiserle(1) \\
\hline 37 & lakin & 7 & 0.36 & lakin(7) \\
\hline 38 & ver & 7 & vererek(1) veriyor $(1)$ & $\begin{array}{l}\text { veren(2) vermiş(1) vermiyordu(1) verir(1) } \\
\text { ) veriyor(1) }\end{array}$ \\
\hline 39 & çıkar & 7 & çıkaramamışlardı(1) çıkaramıyordu(1) & $\begin{array}{l}\text { çıkarıp (1) çıkarırlar(1) çıkarmış(1) çıkardı(1) } \\
\text { Imışlardı(1) çıkaramıyordu(1) }\end{array}$ \\
\hline & & çıkar(1) & & \\
\hline 40 & değil & 7 & 0.36 & değil(4) değildi(3) \\
\hline 41 & $\mathrm{ol}$ & 7 & \multicolumn{2}{|c|}{ olacaktı(1) olsaydı(1) } \\
\hline 42 & oyun & 7 & 0.36 & oyun(4) oyunun(1) oyunda(1) oyunu(1) \\
\hline 43 & rak1 & 6 & 0.30 & $\operatorname{rakinin}(3) \operatorname{rak} 1(3)$ \\
\hline 44 & kadın & 6 & 0.30 & kadın(5) kadınlar(1) \\
\hline 45 & ağır & 6 & 0.30 & ağ1r(6) \\
\hline 46 & daha & 6 & 0.30 & daha(6) \\
\hline 47 & ki & 6 & 0.30 & $\mathrm{ki}(6)$ \\
\hline 48 & zaman & 6 & 0.30 & zaman(4) zamankinden(1) zamanda(1) \\
\hline 49 & sonra & 6 & 0.30 & sonra(6) \\
\hline 50 & başka & 6 & 0.30 & başka(5) başkası(1) \\
\hline 51 & içeri & 6 & 0.30 & içeride(3) içeriye(1) içeriden(1) içeri(1) \\
\hline 52 & misafir & 6 & \multicolumn{2}{|c|}{ misafir(1) } \\
\hline 53 & yer & 6 & $\begin{array}{l}0.30 \\
\text { yer }(1\end{array}$ & yerinden(2) yerlerinde(1) yeri(1) yerdi(1) \\
\hline 54 & kim & 6 & 0.30 & kim(2) kimler(1) kiminle(1) kime(1) kimdi(1) \\
\hline 55 & da & 6 & 0.30 & $\mathrm{da}(6)$ \\
\hline 56 & dişarı & 6 & \multicolumn{2}{|c|}{ dişarıdaki(1) } \\
\hline 57 & ile & 6 & 0.30 & ile(6) \\
\hline 58 & duru & 6 & duruyonuz(1) & $\begin{array}{l}\text { duruyoruz(2) duruyordu(2) duruyor(1) } \\
\text { uz(1) }\end{array}$ \\
\hline 59 & artik & 6 & 0.30 & $\operatorname{artık}(6)$ \\
\hline 60 & yat & 6 & 0.30 & yatan(2) yatiyor(2) yatanlar(1) yatard1(1) \\
\hline 61 & vakit & 5 & 0.25 & vakit(4) vaktini(1) \\
\hline 62 & bura & 5 & 0.25 & buraya(2) burasi(2) burada(1) \\
\hline 63 & hiç & 5 & 0.25 & $\operatorname{hiç(5)}$ \\
\hline 64 & adam & 5 & 0.25 & $\operatorname{adam}(3) \operatorname{adamin}(1) \operatorname{adamd1}(1)$ \\
\hline 65 & kimse & 5 & 0.25 & kimse(5) \\
\hline
\end{tabular}




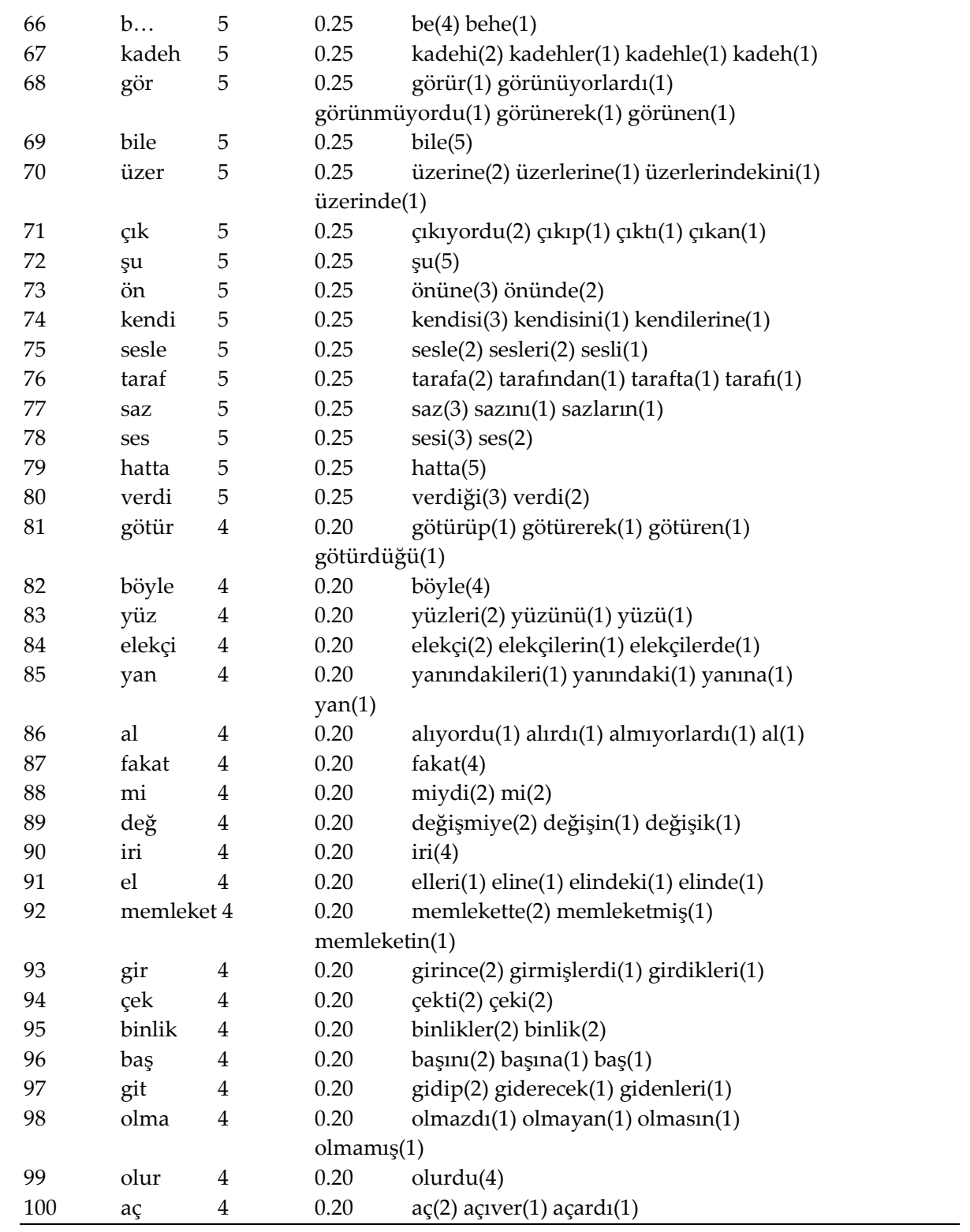

Metnin çıkartılan gövde sıklığı incelendiğinde metnin başkarakteri Sarı Bal bir(96), bu(38), de(32), sıklığ1 çıkarıldığında sarı(20), bal ise bal(8), balı(2), balın(8), bala(1) olmak üzere o da 20 kez kullanılmıştır. Sarı Bal, metinde en çok kullanılan anlamlı bir ifade olmuştur. Eylem olarak en çok gel(17) kullanılmıştır. Hilmi Ağa(12) kez geçmiştir. O(17), göz(14), var(14), iç(13), ne(11), yok(11), kapı(10), altın(10), oda(10), etmek(10), gece, kasaba, 
yatak(9), kez geçmiştir. Bu kelime sıklı̆̆ını okuduğumuzda şöyle bir cümle karşımıza çıkmaktadır: "Hilmi Ă̆a geceleri Sarı Bal'ın odasına gelirdi."

Sarı Bal hikâyesinden bahsederken Sarı Bal'ın mavi gözlerini metinden geçen cümlelerle şu şekilde tamamlamıştır: "öpmek, koklamak, içmek iştihası veren iri mavi gözleri'nde tezahür eden dişiliği etrafında... dolanırlar" (Aktaş, 2004: 69). Metin de geçen sıklıklara baktığımızda O(17), göz(14), var(14) kez geçmiştir. "Sarı Bal'ın güzel gözleri var" şeklinde bir yorum yapmak hiç de yanlış olmaz.

Sarı Bal'ın evinde eğlence tertip edilmektedir. Evde eğlence tertip edildiği kelime sıklıklarına bakınca rahatlıkla anlaşılabilir. Nitekim, oda(10), gece, kasaba, yatak(9), zil(8), oyun(7), rakı(6), kadın(6), kadeh(5), saz(5) kez geçmiştir. Belki şöyle bir yorum yapılabilir: Gece olunca kasabada bir güzel eğlence olurdu. Odalarda sazlar çalınır, kadınlar zil takıp oynar, kadehlerle rakılar içilirdi.

Metin kelime sıklı̆̆ına baktığımızda yazarın hikâye kurgusunu oluşturduğu karakterler, mekânlar ve olay örgüsü hikâyenin bütünü içerisinde kendine yer bulmaktadır. Yazar kaleme aldığı hikâyesinde bu açıdan da oldukça başarılıdır.

\section{Sonuç}

Sarı Bal hikâyesi Refik Halit Karay'ın Memleket Hikâyeleri adlı eserinde geçen diğer hikâyeleri gibi çok güçlü bir anlatım tarzına ve olay örgüsüne sahiptir. Hikâyede, insanların hangi mevkide, hangi görevde olursa olsun ahlaki anlamda bir çöküntüye uğrayabileceği anlatılmaktadır. Hikâyenin ana hatları Sarı Bal diye adlandırılan bir çengi üzerine kurgulanmıştır. Yazar, bu hikâyesinde Sarı Bal'a olan ilgiyi iki karakter üzerinden ironileştirmiş böylece verilmek istenen mesajı daha net okuyucularına aktarmıştır. Hikâyenin kelime sıklığı çıkartıldığında seçilen kelimelerin konunun bütünlüğü içerisinde verildiği açıkça görülmektedir. Karay, bu yönüyle de farklılığını ortaya koymuştur. Hikâye tahlilleri çoğu açıdan ele alınabilir. Tahlillerde karakter, mekân, zaman, bakış açısı ve anlatıcı, dil ve üslup gibi unsurlar başlıklar halinde verile gelmiştir. Bu çalışmada yapılan tahlil denemesinde ise bu unsurlar bir bütünlük içerisinde ele alınmıştır. Hikâyenin kelime sıklığı çıartılarak yazarın seçtiği kelimelerin konunun bütünlüğüne uygunluğu saptanıştır. Denilebilir ki Refik Halit, eserlerini bir kuyumcu titizliğinde oluşturmuş ve en uygun kelimeyi bulana kadar da bu hassasiyetini elinden bırakmamıştır. 


\section{Kaynakça}

Aktaş, Ş. (2004). Refik halit karay, Ankara: Akçağ Yayınları.

Ekiz, O.N. (1999). Refik halit karay. İstanbul: Toker Yayınları.

Gözütok, T. K. (2007). Refik Halit'ten Cumhuriyet Dönemi Hikâyecilerine (1919-1940) Kasaba Olgusu. Modern Türklük Araştırmaları Dergisi, 4(2), 73-93.

Kara, M, Kurt, A. Türkçe Metin Analiz Programlhttp://ihaleka.com/metinanaliz/ (Erişim tarihi 15.11.2011).

Karabulut, D. (2011). Sürgünlük edebiyatı bağlamında Refik Halid Karay'ın yapıtları (Yayımlanmamış Yüksek Lisans Tezi, İstanbul Bilgi Üniversitesi).

Karay, R. H. (2009). Memleket hikâyeleri, İstanbul: İnkılâp Kitabevi.

Tosun, N. (2010). Sürgündeki Öykücü: Refik Halit Karay. Kitap-lık Dergisi. http://tosunnecip.blogcu.com/ (Erişim tarihi 17.05.2015)

Şimşek, Y. (2012). İnsan ve Mekân Bağlamında Refik Halit Karay'ın "Şeftali Bahçeleri" Hikâyesi . ODÜ Sosyal Bilimler Araştırmaları Dergisi, 3(5), 121-134.

Yardım, M. N. (1997). Refik halit karay hayatt-sanatt-eserleri. İstanbul: Boğaziçi Yayınları.

Yıldırım, A., Şimşek H. (2013). Sosyal bilimlerde nitel araştırma yöntemleri. Ankara: Seçkin Yayıncllık. 